Société d'histoire de la révolution de 1848 et des

révolutions du XIXe siècle

43 | 2011

L'ordre électoral : savoirs et pratiques

\title{
Christian ESTÈVE, Le crime de la Saint-Mary de Mauriac, Champs-sur-Tarentaine, Gerbert, 2011, 543 p. ISBN : 978-2-85579-126-5. 32 euros.
}

Jean-Claude Caron

\section{OpenEdition}

Journals

Édition électronique

URL : http://journals.openedition.org/rh19/4181

DOI : $10.4000 /$ rh 19.4181

ISSN : $1777-5329$

Éditeur

La Société de 1848

Édition imprimée

Date de publication : 13 novembre 2011

Pagination : 164

ISSN : 1265-1354

\section{Référence électronique}

Jean-Claude Caron, " Christian ESTĖVE, Le crime de la Saint-Mary de Mauriac, Champs-sur-Tarentaine, Gerbert, 2011, 543 p. ISBN : 978-2-85579-126-5. 32 euros. », Revue d'histoire du XIXe siècle [En ligne], 43 | 2011, mis en ligne le 13 juillet 2012, consulté le 22 septembre 2020. URL : http:// journals.openedition.org/rh19/4181; DOI : https://doi.org/10.4000/rh19.4181

Ce document a été généré automatiquement le 22 septembre 2020

Tous droits réservés 


\title{
Christian ESTÈVE, Le crime de la Saint-Mary de Mauriac, Champs- sur-Tarentaine, Gerbert, 2011, 543 p. ISBN : 978-2-85579-126-5. 32 euros.
}

\author{
Jean-Claude Caron
}

Dans ce fort volume, Christian Estève, par ailleurs auteur de À l'ombre du pouvoir. Le Cantal du milieu du XIXe siècle à 1914, et d'Histoire d'un leveur du Nord-Cantal : François Chabrier (1826-?) ${ }^{1}$, mène l'enquête sur un crime commis à Mauriac en 1825. Pierre Delmas, un aubergiste veuf de 41 ans, père de sept enfants, en est la victime. Encerclant avec minutie l'affaire criminelle, l'auteur la replace dans son époque et son milieu, brosse un large portrait de l'esprit public dans le Mauriac de la Restauration (avec des prolongements chronologiques en amont comme en aval), démêle les inimitiés. Utilisant aussi bien les archives judiciaires que les cotes foncières, la correspondance administrative que les archives municipales, sources primaires dont il donne de larges extraits, Christian Estève dresse au final le portrait d'une société rurale cantalienne dont il révèle les tensions internes et les haines familiales qui se nouent dans un espace clos.

\section{NOTES}

1. . Christian Estève, À l'ombre du pouvoir. Le Cantal du milieu du XIXe siècle à 1914, ClermontFerrand,Presses universitaires Blaise-Pascal, 2002 ; Christian Estève, Histoire d'un leveur du NordCantal : François Chabrier (1826- ?), Champs-sur-Tarentaine, Éditions C.-E., 2007. 